\title{
Ônibus 174: um sequestro, várias visões
}

Rita Nardelli ${ }^{1}$

\section{Resumo}

Neste artigo se investigou a discussão sobre sociedade e cidadania que o sequestro do ônibus 174, ocorrido em 2000, no Rio de Janeiro, provocou. No trabalho, foi feita uma análise da cobertura jornalística imediata e da reelaboração do fato por meio de um documentário. A partir do exame de 89 páginas das edições dos jornais O Globo e Jornal do Brasil que circularam no período de 13 a 20 do mês de junho daquele ano e, com base na análise crítica do filme Ônibus 174, de José Padilha, foi possível apontar as reações provocadas na sociedade pelo episódio, as medidas anunciadas pelas autoridades, os valores que emergiram no debate e as diferentes interpretações sobre o fato.

Palavras-chave: Cidadania. Mídia. Pobreza. Sequestro. Violência.

\section{Introdução}

Dia 12 de junho de 2000, Jardim Botânico, bairro de classe média do Rio de Janeiro: cercado por policiais de elite, Sandro do Nascimento, um homem jovem, pobre, negro, desdentado, mantém onze reféns num ônibus da linha 174 por cerca de quatro horas e meia. Ele faz ameaças, grita, fala muito, descontrola-se, assume o controle da situação, gesticula, atira para o alto, aterroriza os passageiros do veículo. Supõe-se, pelos movimentos bruscos, a irritabilidade e pela verborragia, que esteja drogado. Os reféns - em sua grande maioria, mulheres - demonstram pânico, tentam uma aproximação com o sequestrador, pedem socorro, ficam atônitos. Falta de preparo da polícia, presença da mídia, horas de tensão e um final trágico: a morte de uma refém, Geisa Firmo Gonçalves, após a descida do ônibus, e o fim de Sandro numa viatura policial.

\footnotetext{
1 Jornalista com especialização em História, Sociedade e Cidadania - UniCEUB.
} 
O sequestro do ônibus 174 concentrou, de forma dramática, uma série de questões importantes do tempo presente e que estão relacionadas à cidadania no Brasil urbano. Segurança pública, direitos humanos, abandono de crianças, desigualdade social e ineficiência do Estado foram temas presentes no debate gerado pelo episódio e alimentado por veículos de comunicação de massa do país.

Transmitido em tempo real por emissoras de televisão e com repercussão na mídia internacional, o sequestro de um ônibus da linha 174 (Gávea-Central) alterou a agenda de grupos mobilizados da sociedade e do governo nos dias seguintes ao fato, provocando desde o anúncio de medidas de combate à violência por autoridades estaduais e federais, manifestações de protesto e marchas pela paz, votações no Senado, audiência pública na Assembleia Legislativa do Rio, pesquisas de opinião, um documentário e um filme de ficção, trabalhos acadêmicos, exoneração de autoridades até a inserção do tema na campanha eleitoral para a prefeitura da cidade. Este artigo procura analisar as discussões sobre sociedade e cidadania que tal episódio suscitou. ${ }^{2}$

A partir do acompanhamento da cobertura feita por dois jornais da grande imprensa durante os oito dias subsequentes ao sequestro e do exame de um documentário produzido sobre o caso, serão identificados os valores que emergiram nessa discussão e as reações desencadeadas na sociedade. As pessoas que foram entrevistadas, o espaço conferido às diferentes ideias que circularam na sociedade e a ênfase dada a determinados aspectos da questão serão avaliados na busca de se desvendarem as distintas interpretações dadas ao fato e de se perceber como elas nortearam a reconstituição da história pelos jornais e pelo documentário.

Leituras relativas ao conceito e à história da cidadania foram fundamentais para permitir a análise que se segue. Foram estudados os autores T. H. Marshall (1967) e José Murilo de Carvalho (2008). Na parte relativa à relação entre mídia e cidadania, a análise baseou-se nos trabalhos de Pedrinho A. Guareschi (2000)

\footnotetext{
2 Artigo baseado na monografia apresentada como pré-requisito para a obtenção de título da Pós-Graduação lato sensu (Especialização) em História, Sociedade e Cidadania, do UniCEUB/ICPD, sob a orientação da profa. Rosana Ulhôa Botelho (NARDELLI, 2010).
} 
e Enric Saperas (2000). Para a avaliação da cobertura jornalística, recorremos a conceitos de Eni P. Orlandi (2007) e Martin W. Bauer (2002).

\section{Mídia e cidadania}

Nos últimos anos, um fenômeno não somente brasileiro, mas mundial, o esvaziamento dos sindicatos, a desarticulação da sociedade civil e o descrédito dos partidos políticos provocaram o deslocamento do debate sobre as questões que afetam as comunidades para a mídia, que passou a ser um foro privilegiado de discussão. Não foi diferente no caso do sequestro do ônibus 174 .

No estudo que fizemos, foram analisadas as edições dos jornais $O$ Globo e Jornal do Brasil dos dias 13 de junho de 2000 a 20 de junho de 2000, quando se concentrou a maioria das matérias sobre o sequestro do ônibus 174. Para orientar essa avaliação, foi criado um quadro destinado ao preenchimento de informações relativas aos seguintes itens: página, editoria, fotos (com respectivas legendas e dimensões), matéria principal, outros textos, quadros (gráficos, 'boxes', resultados de enquetes, charges) e falas. Também foram estudadas as opiniões dos leitores e da direção dos veículos, estas explicitadas em editoriais.

Em ambos os jornais, a farta utilização de fotos de grandes dimensões confere maior impacto às notícias. Os veículos de comunicação também se valeram de reprodução de imagens de emissoras de televisão, possivelmente para que se tivesse uma noção do episódio mais próxima do real.

\section{As vozes}

Um levantamento das vozes ouvidas pelos dois jornais indica que ambos tiveram a preocupação não apenas de ouvir as autoridades envolvidas ou que tinham alguma responsabilidade, ainda que indireta, pelo episódio, mas também de detectar de que forma o leitor interpretou os fatos e de obter subsídios para melhor compreensão do problema por meio da audiência a especialistas. 
Nas 52 páginas dedicadas ao episódio pelo $O$ Globo nos oito dias subsequentes ao sequestro, verifica-se uma atenção significativa às opiniões dos cidadãos - 68 pessoas, expressas em entrevistas ou nas cartas dos leitores; uma ênfase dada às manifestações de autoridades - 62; e também uma preocupação em divulgar o entendimento do fato por representantes da sociedade civil - 21 declarações; por especialistas - 18; por parentes e amigos dos reféns - 18; e pelos próprios reféns - 15. Outros dois grupos tiveram suas posições inseridas no jornal por oito vezes, cada um: o de jornalistas (incluída aí a referência, feita de forma genérica, à "imprensa estrangeira") e o de candidatos a prefeito do Rio de Janeiro.

Um espaço menor foi concedido a parentes ou amigos de Sandro - duas pessoas, entre as quais uma sobrevivente da chacina da Candelária. Também foram ouvidos, sem presença expressiva, advogados dos envolvidos, o próprio Sandro do Nascimento - de forma indireta, como não poderia deixar de ser, com a transcrição de quatro de suas falas durante o sequestro -, um representante da área de transporte coletivo do estado, a primeira-dama do Rio de Janeiro e cinco diretores de escolas da região onde o fato ocorreu.

É importante esclarecer que, entre os cidadãos aos quais o levantamento se refere, foram incluídas não apenas pessoas comuns, entendidas aí aquelas que não têm expressão pública, mas também compositores, poetas, atores e cineastas. Como especialistas, foram considerados, entre outros, criminalistas, médicos, sociólogos e um dirigente de um instituto de pesquisa. Já na relação dos representantes da sociedade civil, há dirigentes da Ordem dos Advogados do Brasil, da Igreja Católica, do Movimento Viva Rio, do grupo Tortura Nunca Mais e do Rotary Club, entre outros. Esclarecimento que também se faz necessário é o de que uma mesma pessoa é computada - e enquadrada numa categoria - todas as vezes em que é ouvida pelo veículo de comunicação.

Nas 37 páginas dedicadas ao sequestro do ônibus pelo Jornal do Brasil - o JB - nos oito dias subsequentes ao episódio, foram ouvidos 80 cidadãos, por meio de entrevistas, pesquisas de opinião e cartas; 54 autoridades e 22 representantes da sociedade civil. O segmento que teve mais pessoas consultadas, depois dos já citados, foi o dos especialistas - 15. Há ainda dez falas de reféns, 13 de parentes e amigos 
dos reféns, seis de jornalistas e seis de advogados. Também foram ouvidos quatro representantes de entidades ligadas ao setor de transporte de passageiros. O Jornal do Brasil deu mais espaço do que O Globo a pessoas ligadas ao sequestrador: quatro (entre parentes e amigos), além de três sobreviventes da chacina da Candelária. O jornal publicou apenas duas falas de Sandro do Nascimento durante o sequestro.

Entre os representantes da sociedade civil, estavam dirigentes da Ordem dos Advogados do Brasil, da Igreja Católica, da Anistia Internacional e do Centro Brasileiro de Defesa dos Direitos da Criança e do Adolescente. Como especialistas, foram classificados psicólogos, instrutores de tiro, um jurista e o diretor do Instituto de Criminalística, entre outros.

\section{As perguntas}

Ambos os jornais procuraram aferir sentimentos e percepções a respeito do sequestro do ônibus por meio de pesquisas entre os leitores ou até mesmo fora dos limites do seu público, dentro de uma amostra da população da cidade.

No período analisado, $O$ Globo realizou três pesquisas. Na primeira, formulou uma pergunta sobre o que mais chamou a atenção na edição de 13 de junho de 2000 - um dia após o sequestro - e outra sobre a importância do tema do ponto de vista da sociedade. Na segunda, feita junto aos internautas, o veículo em sua versão on line pretendeu obter opiniões sobre a atuação da polícia carioca. Na terceira, feita com 300 pessoas na Região Metropolitana do Rio de Janeiro pelo Ibope (Instituto Brasileiro de Opinião Pública e Estatística), O Globo procurou conhecer o percentual da população que já havia tido contato próximo com a violência urbana e a opinião majoritária sobre a polícia e o policiamento nos municípios da região.

O JB Online quis saber a opinião dos leitores sobre se a polícia agiu corretamente na ação do ônibus, na pesquisa "Questão do momento" lançada na noite do dia do sequestro. Outra forma de o JB Online aferir a percepção da população a respeito do fato foi a pesquisa sobre a aprovação - ou não - da ação dos policiais que mataram o assaltante após sua prisão. A declaração da refém Luanna Guima- 
rães Belmont de que Sandro também era vítima da sociedade foi objeto de nova pesquisa do JB Online.

\section{As respostas}

A primeira pesquisa feita pelo $O$ Globo, cujos resultados foram divulgados no espaço “O Leitor no Globo”, na página 6 da edição de 14 de junho de 2000, indicou que a manchete "Um erro fatal" - sobre a ação da polícia e a morte da refém Geisa Firmo Gonçalves - foi considerada por 90\% dos entrevistados como o assunto que mais chamou a atenção na edição do dia 13 de junho de 2000. Dos entrevistados, 74\% responderam, na ocasião, que o tema era muito importante do ponto de vista da sociedade, enquanto $25 \%$ o consideraram importante e $1 \%$, pouco importante.

$\mathrm{Na}$ mesma edição em que registrava o resultado dessa enquete, O Globo também informava que, do total de ligações recebidas pelo Serviço de Atendimento ao Leitor, $48 \%$ foram sobre o sequestro - destas, $85 \%$ foram manifestações de revolta e $15 \%$, sugestões de pauta a partir do assunto.

A segunda pesquisa, aquela feita junto aos internautas, mostrou, conforme o jornal, que os leitores estavam revoltados com a ação da polícia no episódio. Publicada em 15 de junho de 2000, na página 18, a matéria "Internautas: ação da polícia militar foi desastrada - Pesquisa do Globo On mostra que leitores estão envergonhados", escrita por Sérgio Maggi, informava que as palavras mais usadas pelos leitores da versão on line do jornal para descrever a atuação da polícia carioca no desfecho do sequestro foram "desastrada", "ineficiente", "negligente" e "imprudente".

Uma preocupação que marcou as opiniões colhidas nesse levantamento relacionou-se à falta de uma política de segurança pública séria e eficiente. Os principais motivos apontados para a ineficiência dos policiais foram os baixos salários, a falta de equipamento adequado e de treinamento e a ligação com criminosos. 
Um ponto chamou a atenção de Maggi: ele classificou de "preocupante" a opinião de cerca de 100 leitores - pouco mais de 15\% do total - que aprovaram o assassinato de Sandro do Nascimento pelos policiais, como se a morte do sequestrador fosse um castigo merecido. Ainda de acordo com a matéria, muitos aproveitaram para defender a adoção da pena de morte no Brasil como solução para o problema da violência nas grandes cidades.

A terceira pesquisa teve seus resultados divulgados na matéria “ $A$ estatística do medo - Pesquisa mostra que maioria no Grande Rio já foi assaltada e desconfia da polícia”, assinada por Laura Antunes, Luciana Conti e Paulo Marqueiro, e publicada na página 16 da edição de dia 18 de junho de 2000. Segundo a matéria, $81 \%$ das pessoas entrevistadas no Grande Rio já tinham sofrido algum assalto ou tiveram alguém da família assaltado; $72 \%$ não confiavam na polícia; $59 \%$ consideravam péssimo ou ruim o policiamento nos municípios da região.

Questionados sobre a saída para melhorar a segurança nos municípios do Grande Rio, 35\% dos entrevistados falaram em aumento do efetivo policial nas ruas, $36 \%$ sugeriram melhor treinamento dos policiais, $12 \%$ manifestaram-se por uma seleção melhor dos policiais, com o objetivo de evitar os corruptos, $9 \%$ defenderam uma mudança em toda a polícia, $4 \%$ defenderam o reaparelhamento da polícia, com investimentos em armas e equipamentos, e um em cada cinco moradores expressou o desejo de que os policiais recebessem salários melhores. Em menor escala, os entrevistados apontaram soluções na área social: 10\% defenderam a geração de emprego como solução para melhorar a segurança pública, $8 \%$ deles sugeriram investimentos em educação e 6\%, na criação de programas sociais. As respostas foram espontâneas.

Nas páginas 6 e 21 a 28 da edição de 14 de junho do Jornal do Brasil, foi divulgada a pesquisa feita sobre se a polícia agiu corretamente na ação do ônibus. As opiniões convergiram: a ação foi qualificada de desastrosa e a polícia, considerada violenta, despreparada e incompetente. Houve críticas aos governantes e à sociedade em geral, indignação com o estágio alcançado pela violência na cidade, descrença no poder público, busca de apoio na religião. O resultado final da pes- 
quisa, divulgado na matéria “Acesso online sobe 400\%”, página 24 da edição de dia 15 de junho, indicou que $71,66 \%$ dos leitores criticaram a polícia.

Já a enquete feita pelo $J B$ sobre a ação dos policiais que mataram Sandro apresentou em seu resultado, divulgado na primeira página da edição de 15 de junho, uma divisão equilibrada entre os que aprovaram a ação dos policiais de estrangular Sandro - 45,03\% - e os que condenaram tal atitude - 44,35\%.

A declaração de Luanna de que Sandro também era vítima da sociedade, objeto de pesquisa do JB Online, recebeu, conforme nota na primeira página da edição do dia 16 de junho, o apoio de 59,79\% dos que responderam. Apenas $32,21 \%$ discordaram de Luanna e $8,01 \%$ não se definiram.

\section{Críticas à polícia}

A responsabilidade da polícia pelo trágico desfecho do sequestro do ônibus 174 foi amplamente explorada tanto pelo O Globo como pelo Jornal do Brasil, que, no dia seguinte ao fato, cobraram providências das autoridades para a redução da violência no Rio de Janeiro.

Nos primeiros dias após o sequestro, grande parte de $O$ Globo foi dedicada aos erros da polícia. No editorial intitulado "O que o povo viu”, publicado na página 6 no dia 14 de junho de 2000, por exemplo, o jornal fez críticas à forma com que o sequestro foi administrado pela Secretaria de Segurança e pelo governo do estado e afirmou que "o povo está convencido de que a polícia, mais do que ineficiente, é ela própria um fator de insegurança”. Na primeira página da edição, $O$ Globo relacionou o que considerava uma sucessão de absurdos: "Primeiro tiro em Geisa foi da polícia. Bandido não levou um tiro sequer. Policiais estrangularam sequestrador no camburão".

Na edição de 13 de junho, dia seguinte ao do sequestro, portanto, o JB tinha como manchete "Incompetência e morte - quatro horas de terror, dois mortos 
e dúvidas" e apontava o insucesso da Polícia Militar (PM) do Rio de Janeiro, em matéria publicada na página 18 , sob o título "PM do Rio fracassa e refém morre". No dia seguinte, na primeira página, o $J B$ voltou a empregar, dessa vez na legenda de uma foto, a palavra "incompetência" para se referir à polícia e registrou que houve precipitação dos policiais.

Também mereceram críticas, desta vez por parte dos leitores, os políticos, especialmente por sua omissão em relação aos graves problemas brasileiros. As declarações dos leitores apontaram ainda uma sensação de impotência diante da violência.

\section{Matar ou não matar...}

Em alguns depoimentos ou textos, o fato de a polícia não ter atirado em Sandro durante o sequestro é alvo de questionamentos.

Na primeira página da edição do dia 13 de junho de 2000 de $O$ Globo, por exemplo, uma das fotos é encabeçada pelo título "Por que não atiraram antes?". No dia 14 de junho, na página 18, as legendas seguem a mesma linha. Uma delas é a seguinte: "Oportunidade perdida (grifos nossos): o bandido chega à janela e põe a arma para fora do ônibus, com todos os reféns completamente fora de sua mira”. Em outra, a frase é: "Nova chance desperdiçada (grifos nossos): a arma está apontada para o para-brisa”. E a terceira legenda da página: “Cabeça na janela do ônibus: o revólver está virado para o chão". As fotos ilustram a matéria “Especialistas apontam falhas na ação da PM".

Já na edição de 13 de junho do Jornal do Brasil, na página 18, um texto recebe o título de "Atiradores poderiam ter agido". Privilegia, assim, a informação de que os policiais poderiam ter matado o sequestrador, em detrimento de outras várias informações, como a de que a orientação da Secretaria de Segurança era de que a polícia esgotasse todos os meios de negociação com o criminoso ou a de que o órgão havia dado ordens ao Bope para que tanto o criminoso quanto os reféns saíssem vivos do ônibus. 
O episódio reavivou a defesa da pena de morte, questão debatida nos anos 1990, quando tramitou no Congresso Nacional proposta do então deputado Amaral Netto para a realização de um plebiscito sobre a adoção desse instrumento punitivo em determinados casos.

Sandro deveria ou não morrer? Essa questão foi respondida nas ruas por populares que, acompanhando a transmissão ao vivo do sequestro na televisão ou aglomerando-se perto do ônibus, manifestaram o desejo de ver Sandro morto. Também foram respondidas em inúmeras manifestações de leitores dos dois jornais - e aí nota-se certo equilíbrio entre aqueles que queriam ver Sandro morto ou apoiaram seu assassinato no camburão e aqueles que defendem que o Estado não pode ser justiceiro.

A desqualificação das pessoas que se engajam em movimentos em defesa dos direitos humanos é percebida em algumas intervenções. Há uma manifesta má vontade, por parte de alguns cidadãos, com os defensores dos direitos humanos. Esse sentimento foi divulgado em ambos os jornais pesquisados, mas não foi assumido pelos veículos de comunicação como bandeiras.

\section{Uma história diferente}

Privilegiar a questão da segurança e minimizar a questão social no caso do sequestro do ônibus 174 é uma postura identificável na maioria das declarações das autoridades e em muitas das falas dos cidadãos consultados, veiculadas durante o período estudado. Os aspectos ligados à segurança também tiveram espaço privilegiado na cobertura dos jornais. Nota-se uma ênfase em assuntos relacionados à segurança pública, como aumento do efetivo policial, treinamento dos agentes e reaparelhamento da polícia. Isso aparece, sobretudo, em O Globo, já que, no Jornal do Brasil, as questões sociais ganham maior relevo.

Há um momento, entretanto - na página 23 da edição de 18 de junho - em que $O$ Globo garante um espaço expressivo para trabalhos em favor de jovens que moram em áreas de risco, apresentando, assim, outro caminho que, se bem suce- 
dido, levaria à redução da criminalidade. O texto conta a história de Edson, de dez anos de idade, que, segundo o jornal, está "driblando o analfabetismo e buscando escrever uma história diferente de quem vive numa zona de risco no Rio de Janeiro, no fio da navalha entre a violência do tráfico e a pobreza”.

A preocupação com a questão social aparece em várias declarações publicadas no $O$ Globo, ainda que neste jornal predomine o material sobre a questão da segurança em seu sentido estrito.

A exemplo do editorial de $O$ Globo, o do $J B$ também não tratou das questões sociais que envolvem o episódio. Intitulado "Carrascos e vítimas” e publicado na edição do dia 14 de junho, página 8 , o texto referiu-se aos erros da polícia e afirmou que, em determinados momentos, esta se arvorava em defensora, julgadora e carrasco. Mas, no decorrer da cobertura, o $J B$ foi abrindo espaço para pessoas e instituições que apontavam, especialmente, para as questões sociais que envolveram o sequestro do ônibus 174 .

No dia 15 de junho, por exemplo, na página 24, o Jornal do Brasil divulgou matéria intitulada "Anistia critica sistema carcerário" com os principais pontos de relatório da Anistia Internacional segundo o qual as condições subumanas dos presídios, as torturas nas delegacias de polícia e os assassinatos de menores de rua continuavam sendo um "mal endêmico" no Brasil.

No exterior, a ênfase na cobertura jornalística recaiu sobre a questão da desigualdade social existente no Brasil.

\section{Sandro nas manchetes}

Outro aspecto que surgiu neste estudo refere-se à forma como Sandro do Nascimento foi qualificado pelo jornal e pelos leitores.

Com fotos de grandes dimensões e forte impacto, $O$ Globo qualificou o sequestrador de "bandido sanguinário e frio" na matéria "Terror e sangue no Rio", 
publicada na página 15 da edição de 13 de junho. No dia 14 de junho, a matéria principal da página 22 do jornal, assinada por Angelina Nunes, intitula-se “Terror: ex-menino de rua escapou da chacina, vivia de furtos e assaltos e usava quatro nomes e apelidos. Bandido era sobrevivente da Candelária". Na abertura da matéria, informa-se que "identificado como Sandro do Nascimento, o bandido teve um passado de menor de rua viciado em cola, que praticava furtos e assaltos em esquinas e sobreviveu à chacina da Candelária, há sete anos".

No corpo da matéria, duas vozes ligadas a Sandro foram ouvidas: a de uma das sobreviventes da Candelária, afirmando que Sandro "falava que os pais tinham morrido de uma forma trágica e ficava transtornado", e a da artista plástica Yvonne Bezerra de Mello, que desenvolvia um trabalho assistencial junto aos menores da Candelária. Yvonne relatou ao jornal que Sandro estava magro, com fome, pedindo emprego e que ele lhe havia dito que teria uma oportunidade no fim de junho. Ainda segundo Yvonne, na época da Candelária, Sandro era um menor como os outros e não apresentava comportamento agressivo.

Nessa edição, também na página 22, há um texto sobre a chacina da Candelária - "Em julho de 93, oito mortos em frente à igreja" - e outro, assinado por Antônio Werneck, que trata da ficha policial de Sandro - "Sandro telefonou para pedir ajuda a cúmplice". No segundo texto, o jornal afirma: "Um homem frio, violento, especializado em assalto à mão armada e que atuava preferencialmente na Zona Sul do Rio: a ficha de Sandro, de 22 anos, não deixa dúvidas. Condenado por um assalto à mão armada a três anos e seis meses de prisão, e por furto qualificado, pena de dois anos, Sandro era considerado pela polícia um bandido perigoso".

No dia 15 de junho, O Globo informava, na matéria principal da página 19, assinada por Antônio Werneck - "Um homem sem identidade revoltou o Rio" -, que uma doméstica, Elza da Silva, afirmava ser mãe do sequestrador, o reconheceu no Instituto Médico Legal, mas corria o risco de sepultá-lo como indigente. Segundo O Globo, a história de Alex - que seria o nome de Sandro, conforme a doméstica - "é cheia de percalços". O jornal informava que Elza teria entregado o filho a uma amiga, por não ter condições de criá-lo, e que, quatro anos depois, resolveu ir atrás do menino, quando soube que a amiga havia morrido e não teve mais notícias do 
filho. Alex teria crescido nas ruas e aos 18 anos começou a procurar a mãe, tendo encontrado Elza - com quem viveu por três meses - dois anos depois. E registrava que Sandro, num vídeo caseiro sobre a festa conjunta de aniversário dos meninos da Candelária, chegava discretamente, subia na mureta e ficava observando seus colegas dançarem.

O fato de o sequestrador ser sobrevivente da chacina da Candelária aparece na matéria principal da página 23 da edição do dia 14 de junho do Jornal do Brasil. No texto, intitulado "Vitima e algoz têm o mesmo fim", o jornal afirmava que Geisa ajudava jovens carentes para evitar que acabassem como o sequestrador que tirou sua vida. Informava que tanto o sequestrador quanto a refém sonhavam em ter uma família - Sandro viveu sozinho nas ruas desde os sete anos de idade e Geisa estava grávida após um aborto espontâneo. E ressaltava que o sonho de Geisa de ser mãe havia sido interrompido "depois da desastrada ação policial no desfecho do sequestro", enquanto o sonho de Sandro de pertencer a uma família "foi definitivamente sepultado no interior de uma "patamo" a caminho do hospital".

O JB mostrou que Sandro não teve alternativa à vida no crime, ao contrário dos alunos de Geisa, que ensinava artesanato na Rocinha. E publicou, na mesma página, dois textos complementares: um sobre a dedicação da refém a crianças carentes "para que elas não se tornassem marginais" - "Uma jovem dedicada às crianças" - e outro, com foto dos sobreviventes da chacina da Candelária com a artista plástica Yvonne Bezerra de Mello, sobre o destino de Sandro - "No Jardim Botânico via Candelária”.

Nesse segundo texto, o jornal revelou que Sandro teve o mesmo destino de outros 39 meninos de rua que presenciaram a chacina da Candelária em 1993: "Envolvido com o crime, ele foi assassinado ainda jovem sem ter tido oportunidade de ter a família que sempre sonhou”. O JB transcreveu informações dadas sobre Sandro por Yvonne Bezerra de Mello: ele dormia em uma praça do Catumbi, pedia ajuda para conseguir trabalho. Quando criança, era franzino e bobinho e não sabia ler nem escrever. Após a chacina, passou por diversas instituições de recuperação de menores, mas acabou voltando para a rua. 
Nessa matéria, estão os dados que antecipam a tragédia do sequestro do ônibus: um menino de rua, sem perspectivas, analfabeto e que, ao retornar às ruas depois de passar por diversas instituições de recuperação de menores, encarnava a incompetência do Estado e da sociedade para resgatar a dignidade dessas crianças e encaminhá-las a um futuro melhor.

Na mesma edição de 14 de junho e na mesma página, o JB publicou texto sobre o "Reencontro com o filho pela TV" da mulher que se dizia mãe de Sandro. Novamente, o jornal se referiu à trajetória do sequestrador, lembrando que ele foi viver nas ruas com apenas sete anos, após a morte da mãe de criação, e que foi preso por assalto à mão armada em 1998. E publicou declarações de Elza da Silva, que se apresentou como mãe de Sandro, de que, no período em que viveram próximos, descobriu um filho carinhoso, mas assustado. Segundo ela, Sandro tinha pesadelos e dizia ter medo de o sonho acabar.

Na página 23 da edição de 15 de junho, o jornal voltou a dedicar espaço à vida de Sandro. Na matéria principal, intitulada "Sobrevivente da Candelária se envolveu com traficantes após a chacina e foi detido seis vezes - Primeiro crime aos 14 anos", o JB registrou que, menos depois de um ano da chacina da Candelária, Sandro cometeu o primeiro crime.

Novamente, na mesma edição, ainda na página 23, o $J B$ entrevistou Yvonne Bezerra de Mello. Ela disse acreditar que haviam sido os seis meses entre os menores infratores que aproximaram Sandro do crime e que ele era um garoto sem muita expressão: "Com certeza, ele era um bandido meio bobo, nem imaginava que poderia causar todo esse transtorno" - avaliou, referindo-se ao sequestro do ônibus 174. Também foi ouvida a advogada do Centro Brasileiro de Defesa dos Direitos da Criança e do Adolescente (CBDDCA), Cristina Leonardo. Segundo ela, Sandro era um menino de rua que não recebeu apoio do Estado e foi parar no crime. Tendo conhecido Sandro de perto, disse que ele era quieto e tímido: "Era um menino tranquilo, que não costumava furtar como os outros e não era dos mais violentos" - acrescentou.

No dia 19 de junho, o jornal fez um relato pungente sobre o destino dos meninos da Candelária. Sob o título "Marcados para morrer", o texto, editado na 
primeira página e assinado por Luciana Cabral, informava que, no dia da chacina, havia 72 crianças dormindo na rua, enroladas em cobertores velhos, em uma noite fria de julho de 1993, ao redor da Candelária. Informava também que oito delas foram executadas antes de o dia nascer, e que, dos sobreviventes - "como em um tabuleiro em que as peças tombam" -, 40 foram assassinados, cinco morreram de Aids, seis estavam presos, dois eram gerentes do tráfico, um estava doente, apenas cinco tinham vida digna e cinco viviam na rua.

Na página 18 da edição do $J B$ do dia 19 de junho, a matéria principal "Uma chacina que dura 7 anos", uma continuação do texto da primeira página - dava novos dados sobre os meninos da Candelária, afirmando que, assim como Sandro, a maioria dos menores sobreviventes da chacina não escapou da violência e da miséria, segundo constatou o CBDDCA. Ainda de acordo com a matéria, o tráfico quase sempre foi a causa das mortes e das prisões. A artista plástica Yvonne, entrevistada mais uma vez pelo jornal, disse que foi um total fracasso a tentativa de afastar os meninos do crime sem a ajuda do Estado. E a advogada do CBDDCA, Cristina Leonardo, declarou que estava sendo preciso "o sacrifício de muitas vítimas para modificar o comportamento de uma sociedade demagógica e hipócrita”.

No mesmo dia e na mesma página, um texto intitulado "Perdidos no mundo", também de Luciana Cabral, dava mais detalhes sobre a vida de alguns dos sobreviventes da chacina.

\section{0 documentário}

O que se viu e ouviu durante a transmissão ao vivo do sequestro e que, no jargão das notícias da época, paralisou o país, é uma pálida imagem da realidade. Se os jornais avançaram no tratamento da questão, a investigação e a reelaboração do fato pelo documentário permitiram o contato com novos aspectos do episódio. Com o filme, até mesmo pelo tempo permitido à sua elaboração, muito maior do que do aquele concedido aos jornais na cobertura diária, foi possível se ter uma avaliação mais ampla de tudo o que estava envolvido no sequestro. 
"Ônibus 174" mescla imagens e sons do cerco policial captadas por emissoras de televisão e por câmeras da Companhia de Engenharia de Tráfego-Rio com imagens da cidade e de meninos de rua, do interior do ônibus - inclusive cenas fortes, como as de Sandro com a arma na boca de Geisa ou encostada na testa de Luanna -, dos entrevistados, de reportagens sobre a chacina da Candelária. E se propõe, entre outros objetivos, a contar outro lado da história: o da vida de Sandro do Nascimento, marcada pela violência familiar e policial, pelo abandono do Estado, pela omissão da sociedade.

As primeiras imagens já anunciam o tom do discurso que sustentará o documentário. Tomadas aéreas denunciam as desigualdades sociais extremas que há no Rio de Janeiro, representadas por apartamentos de cobertura com piscinas ao lado de barracos precariamente instalados nos morros cariocas.

A eleição dos depoimentos também revela como o diretor reconstitui a história do sequestro. As primeiras falas são de meninos e meninas de rua e estão impregnadas de um sentimento de desesperança. É a voz dos excluídos, sempre em off, acompanhada de cenas do Rio de Janeiro.

A artista plástica Yvonne Bezerra de Mello, que desenvolvia um trabalho com as crianças que dormiam na calçada da Candelária, tem sua entrevista inserida em diversos momentos do filme. São igualmente entrevistados dois sobreviventes da chacina da Candelária, uma tia de Sandro, uma senhora que o acolheu como se fosse seu filho, um funcionário de uma delegacia onde ele passou um período preso, tudo para compor um painel do sequestrador. O documentário ouve ainda representantes da polícia - inclusive um policial do Bope que se esconde sob um capuz para criticar a atuação da polícia no sequestro - e da imprensa, especialistas em segurança e reféns.

Alguns temas pouco tratados pela imprensa escrita ganham corpo no documentário. É o caso, por exemplo, das diferenças entre o policial do Bope e o da Polícia Militar. Também é o caso do ingresso na PM por falta de perspectivas, pelo insucesso na inserção no mercado de trabalho. Outra questão abordada no filme, desprezada pela mídia escrita, é a do poder que Sandro adquiriu com a cobertura imediata do sequestro feita pela mídia. 
O filme trata ainda da invisibilidade dos menores de rua, brilhantemente descrita pelo ex-secretário nacional de Segurança Pública, o antropólogo Luiz Eduardo Soares, e do descaso da elite brasileira em relação a esse grupo social. Temas que igualmente recebem tratamento diferenciado no filme são a vida dentro de instituições de recuperação de menores infratores e as condições subumanas das delegacias.

Outra questão revelada no filme é a existência de um diálogo paralelo dentro do ônibus: havia o que estava acontecendo para as câmeras de televisão, para o lado de fora, e o que ocorria dentro do veículo. A encenação que tornava mais dramática a situação das reféns era controlada por Sandro, conforme observa a refém Luanna Belmont.

“Ônibus 174" apresenta, assim, uma série de questões não vistas na imprensa escrita e muito menos na transmissão ao vivo pelas emissoras de televisão e nos leva a tentar compreender melhor o episódio em todas as suas significações.

\section{Considerações finais}

A repercussão do sequestro do ônibus 174 em junho de 2000 certamente foi inflada por dois fatos: o sequestro ocorreu em um bairro de classe média alta no Rio de Janeiro e foi transmitido ao vivo, em tempo real, por emissoras de televisão.

Questões relacionadas à sociedade e à cidadania surgiram no debate sobre o episódio, alimentado pelos meios de comunicação de massa. A violência urbana, a inépcia do Estado, o desamparo dos meninos de rua e a arbitrariedade policial foram temas que emergiram nos dias subsequentes ao sequestro.

A população reagiu de diferentes formas - com medo, com apelos em favor da paz, com apoio ao assassinato de Sandro do Nascimento e até mesmo com o desejo de ter tido a oportunidade de linchá-lo, com protestos pela falta de segurança, com cobranças às autoridades. Nas manifestações, havia pedidos de paz e lamento pela morte da refém Geisa Firmo Gonçalves. O que levou as pessoas a 
mobilizarem-se foi o sofrimento dos reféns, a violência tão próxima e tão virulenta, a impotência - razões mais do que justificáveis. No entanto, outras reivindicações que caberiam - atenção do Estado para com os menores de rua, políticas públicas em favor da inclusão social, investimentos em educação, por exemplo - praticamente não entraram em pauta.

O registro de opiniões colhidas por dois grandes jornais do Rio de Janeiro revelou valores e reações díspares. As bandeiras da paz e da adoção da pena de morte alternaram-se e a responsabilidade pela violência foi atribuída ora à polícia, ora ao governo estadual ou federal, ora ao sequestrador, ora ao diabo. Todos ficaram chocados com a morte da refém; nem todos manifestaram pesar ou indignação com a morte de Sandro do Nascimento.

Muitos não viram além do episódio e cingiram suas impressões à atuação da polícia; outros contextualizaram o fato, relacionando-o a uma série de questões e vendo o crime não como um ato individual, mas como consequência de uma omissão coletiva em relação aos problemas sociais existentes no país. As autoridades, com raras exceções, analisaram o fato apenas do ponto de vista da segurança pública; os leitores e os entrevistados dividiram-se entre aqueles que discutiram somente questões relacionadas à segurança e os que apontaram aspectos sociais que envolveram o sequestro do 174 .

Uma análise das edições de O Globo e do Jornal do Brasil nos oito dias subsequentes ao sequestro mostra que os dois periódicos amplificaram as diferentes vozes que se levantaram para opinar sobre o fato, apontar culpados, apresentar propostas. Houve um interesse de ambos os jornais em aprofundar os conhecimentos técnicos sobre o episódio, discutir a questão da segurança pública, ouvir especialistas sobre a forma de abordagem, a arma adequada e a condução das negociações num sequestro com reféns.

Os dois veículos de comunicação abriram suas páginas ainda para a sociedade civil, acolhendo opiniões de representantes de entidades e de figuras expressivas da comunidade. E garantiram espaço relevante para duas reféns que avançaram na compreensão do episódio ao não se limitarem ao fato em si e ao considerarem 
diversos fatores, o que as levou à percepção de que Sandro do Nascimento era produto de uma sociedade profundamente injusta.

O Jornal do Brasil, no entanto, conferiu um espaço maior às informações que iriam compor um painel sobre a trajetória do sequestrador e sobre o menor abandonado no Brasil. O número de matérias do JB enfatizando a questão social superou o das reportagens com essa abordagem publicadas em O Globo.

Em sete textos, o JB tratou da vida de Sandro do Nascimento - desde o abandono na infância, passando pela presença no momento do assassinato da mãe adotiva e de amigos de rua e pelo suposto reencontro com a mãe, até a passagem por abrigos e ao desejo do sequestrador de ter uma família -, da chacina da Candelária e do destino das crianças que sobreviveram ao massacre, do sistema penitenciário brasileiro, dos centros de internação de menores e do extermínio de meninos de rua. O Globo veiculou um total de quatro matérias sobre a vida de Sandro e a chacina da Candelária, sobre a história da suposta mãe e sobre um projeto na Favela da Maré que oferece alfabetização e cursos profissionalizantes a menores moradores de áreas de risco.

A forma de ilustrar as matérias também nos dá pistas do que se quer realçado. Na principal matéria do JB sobre a chacina da Candelária, publicada no dia 19 de junho na primeira página - o que já indica a valoração dada pelo jornal à reportagem - sob o título "Marcados para morrer", há duas fotos pequenas de Sandro: uma de quando ele era criança e outra do dia do sequestro. Na matéria que dá continuidade a essa manchete, publicada na página 18 , há uma grande foto da calçada que fica em frente à igreja onde ocorreu a chacina, com ilustrações que registram o destino das crianças que ali dormiam no dia do massacre: cinco mortas por Aids, 40 assassinadas, cinco recuperadas. Texto sobre o que aconteceu com outros sobreviventes que estão em presídios ou instituições intitula-se "Perdidos no mundo".

Em outra matéria que faz referência à chacina da Candelária, o $J B$ exibe uma foto de 1993 em que Sandro, ainda menino, aparece com a cabeça recostada no peito de Yvonne Bezerra de Mello que, sentada, tem em seu colo mais dois meninos de rua. Em volta da artista plástica, outros menores abandonados. 
Na matéria em que trata da chacina da Candelária, no dia 14 de junho, o $O$ Globo publica duas fotos de Sandro: uma de grandes dimensões $(13,5 \mathrm{~cm} \times 21 \mathrm{~cm})$ em que o sequestrador aparece com a identificação feita na $12^{\text {a }}$ Delegacia de Polícia - uma placa pendurada no pescoço com a data da prisão, o artigo do Código Penal infringido, o número do flagrante - e outra feita durante o sequestro do ônibus 174 .

As perguntas formuladas nas pesquisas do $J B$ parecem também indicar uma intenção de destacar questões relacionadas aos direitos humanos em seu sentido mais amplo. Relembrando: o jornal quis saber se os leitores apoiavam a ação policial de matar Sandro do Nascimento após sua prisão e se concordavam com a declaração da refém Luanna Belmont Guimarães de que Sandro também era vítima da sociedade. Com essas duas enquetes, o veículo deu mais visibilidade a duas questões cruciais: a violência policial e a situação do menor abandonado. Uma terceira questão era sobre como os leitores avaliavam a atuação da polícia durante o sequestro.

Das três pesquisas de $O$ Globo, apenas uma tangenciava a questão social, ao perguntar sobre a importância do episódio do ponto de vista da sociedade. Outra se referia à atuação da polícia carioca, e uma terceira pretendia aferir o percentual da população que já havia tido contato próximo com a violência urbana e a opinião majoritária sobre a polícia e o policiamento nos municípios da região. São perguntas que se restringem mais à questão da segurança pública.

Quanto ao documentário, é possível afirmar que o filme amplia significativamente a visão dos fatos, ao buscar mais informações sobre a vida de Sandro, ao ouvir amigos e familiares do sequestrador, sobreviventes da chacina da Candelária, pessoas comprometidas com o atendimento a menores de rua e estudiosos oriundos das Ciências Sociais, e ao investigar como foi a passagem, por abrigos de menores e penitenciárias, de Sandro do Nascimento - que tem uma trajetória comum à dos meninos de rua do Brasil, uma mescla de pobreza, desagregação familiar, 
violência doméstica, abandono, fome, frio, criminalidade, violência policial, falta de reconhecimento.

É um filme que se vincula àqueles que ultrapassam os clichês, os pré-julgamentos. Que se alia àqueles que veem em um fato como o do sequestro do ônibus 174 diversas questões subjacentes, como a miséria, a invisibilidade, a injustiça social, o desrespeito aos direitos humanos, a infância condenada.

Vê-se, assim, que um mesmo episódio pode ser avaliado de diferentes formas a partir da perspectiva de quem o analisa. Isso reforça o papel da mídia na construção de percepções e confere aos veículos de comunicação - não apenas os que transmitem de forma imediata os acontecimentos, mas também os que reelaboram os fatos na tentativa de desvendar o que há por detrás deles - uma grande responsabilidade na construção da cidadania.

\section{Bus: a hijacking, a lot of views}

\section{Abstract}

This article is based on a monograph that looked into the debate over society and citizenship that came up with the 174 bus hijacking, occurred in Rio de Janeiro, in 2000. For that, done an analysis of the immediate journalistic coverage and the fact worked out trough a documentary. From the 89 pages of $\mathrm{O}$ Globo and Jornal do Brasil editions, circulated in June of that year, and still from the study of the movie picture Ônibus 174 , by José Padilha the society reactions from that episode are appointed, as well as the announced authorities measures, the values that emerged from the debate and the different interpretations over the fact.

Keywords: Citizenship. Media. Poverty. Hijacking. Violence. 


\section{Referências}

BAUER, Martin W.; GASKELL, George. Pesquisa qualitativa com texto, imagem e som: um manual prático. Tradução de Pedrinho A. Guareschi. 5. ed. Petrópolis, RJ: Vozes, 2002.

CABRAL, Luciana. Marcados para morrer. Jornal do Brasil, [s.l.], 19 jun. 2000.

CABRAL, Luciana. Perdidos no mundo. Jornal do Brasil, [s.l.], p. 18, 15 jun. 2000.

CARVALHO, José Murilo de. Cidadania no Brasil: o longo caminho. 10. ed. Rio de Janeiro: Civilização Brasileira, 2008.

EM JULHO de 93, oito mortos em frente à igreja. O Globo, [s.l.], p. 22, 14 jun. 2000.

GUARESCHI, Pedrinho A. et al. Os construtores da informação: meios de comunicação, ideologia e ética. Petrópolis, RJ: Vozes, 2000. Coleção Psicologia Social.

MARCONDES FILHO, Ciro. Comunicação e jornalismo: a saga dos cães perdidos. São Paulo: Hacker Editores, 2000. Coleção Comunicação.

MARShAlL, T. H. Cidadania, classe social e status. Tradução de Meton Porto Gadelha. Rio de Janeiro: Zahar Editores, 1967. Introdução de Phillip C. Schmitter.

MELLO, Yvonne Bezerra de. Entrevista. Jornal do Brasil, [s.l.], p. 23, 15 jun. 2000.

MORAES, Dênis de (Org.). Sociedade midiatizada. Traduções de Carlos Frederico Moura da Silva, Maria Inês Coimbra Guedes e Lúcio Pimentel. Rio de Janeiro: Mauad, 2006.

MORAES, Dênis de. Por uma outra comunicação: mídia, mundialização cultural e poder. Rio de Janeiro: Record, 2003.

NO JARDIM Botânico via Candelária. Jornal do Brasil, [s.l.], p. 23, 14 jun. 2000.

NUNES, Angelina. Terror e sangue no Rio. O Globo, [s.l.], p. 15, 13 jun. 2000.

ÔNIBUS 174. Direção: José Padilha. Riofilmes, 2002. 1 DVD (133 min).

ORLANDI, Eni P. Análise de discurso: princípios \& procedimentos. 7. ed. Campinas, SP: Pontes, 2007. 
PRADO, José Luiz Aidar (Org.). Crítica das práticas midiáticas: da sociedade de massa às ciberculturas. São Paulo: Hacker Editores, 2002.

REENCONTRO com o filho pela TV. Jornal do Brasil, [s.l.], p. 23, 14 jun. 2000.

SAPERAS, Enric. Os efeitos cognitivos da comunicação de massas: as recentes investigações em torno dos efeitos da comunicação de massas: 1970/1986. Tradução: Fernando Trindade. 2. ed. Porto: Edições Asa, 2000. Coleção Comunicação/Acção.

SOBREVIVENTES da Candelária se envolveu com traficantes após a chacina e foi detido seis vezes: primeiro crime aos 14 anos. Jornal do Brasil, [s.1.], p. 23, 15 jun. 2000 .

TERROR: ex-menino de rua escapou da chacina, vivia de furtos e assaltos e usava quatro nomes e apelidos: babdido era sobrevivente da Candelária. O Globo, [s.l.], p. 22,14 jun. 2000 .

UMA CHACINA que dura 7 anos. Jornal do Brasil, [s.l.], p. 18, 15 jun. 2000.

UMA JOVEM dedicada às crianças. Jornal do Brasil, [s.l.], p. 23, 14 jun. 2000.

VÍTIMA e algoz têm o mesmo fim. Jornal do Brasil, [s.l.], p. 23, 14 jun. 2000.

WERNECK, Antônio. Sandro telefonou para pedir ajuda a cúmplice. O Globo, [s.l.], p. 22, 14 jun. 2000.

WERNECK, Antônio. Um homem sem identidade revoltou o Rio. O Globo, [s.l.], p. 19, 15 jun. 2000. 


\section{Para publicar na revista Universitas Humanas, acesse 0 endereço eletrônico www.publicacoesacademicas.uniceub.br. Observe as normas de publicação, para facilitar e agilizar o trabalho de edição.}

